\title{
ANALISIS METODE PENCATATAN PERSEDIAAN AIR MINERAL AQUA PADA UD KALTIM MAKMUR DI KABUPATEN BERAU.
}

\author{
Siti Munawaroh \\ siti010890@gmail.com \\ Universitas Muhammadiyah Berau
}

\begin{abstract}
A good inventory system can be seen from how an inventory is reported correctly and accurately on the company's balance sheet. In order for this to be achieved, it is necessary again to be precise and precise in terms of recording, appraising and determining the cost of goods. Apart from being very influential in the company's financial statements, this will also affect the supervision of the company's inventory which is indirectly related to the supervision of the company's employees itself.

The purpose of this study was to clearly determine the application of the method of recording and assessing the Aqua Mineral Water supply at UD Kaltim Makmur in accordance with PSAK No. 14 concerning Inventory. The analytical method used in writing this thesis is quantitative descriptive analysis.

The results of this study concluded that the application of the Aqua Mineral Water supply recording method at UD Kaltim Makmur was not in accordance with PSAK No. 14. The inventory recording method used by UD Kaltim Makmur is the periodic method. The use of the periodic recording method at UD Kaltim Makmur is not in accordance with PSAK No. 14, which should use a perpetual method or with the use of inventory cards. UD Kaltim Makmur calculates the inventory value without using the cost formula required in PSAK No. 14, so the method used by UD Kaltim Makmur is not in accordance with PSAK No. 14.
\end{abstract}

Key word: Inventory, Periodic Method, Perpetual Method.

\section{PENDAHULUAN}

Persediaan merupakan bagian yang paling aktif dalam operasi perusahaan yang secara terus menerus dibeli atau diproduksi dan dijual. Perlakuan akuntansi terhadap persediaan pada perusahaan harus benar-benar diperhatikan karena sistem persediaan yang baik tentunya akan mempengaruhi perolehan keuntungan yang akan menjamin kelangsungan hidup perusahaan. Pengertian persediaan sangat tergantung pada jenis operasional perusahaan. Pada perusahaan dagang, persediaan adalah barang-barang yang dibeli dan dijual oleh perusahaan tanpa mengadakan perubahan yang berarti terhadap barang yang bersangkutan. Dalam perusahaan industri, istilah persediaan meliputi persediaan bahan baku, barang dalam proses dan barang jadi (Nuh dan Hamizar, 2007:81).

Perusahaan yang bergerak di bidang perdagangan barang selalu berhubungan dengan persediaan, sehingga pengelolaan terhadap persediaan harus dilaksanakan sebaik mungkin agar perusahaan tidak mengalami hambatan dan gangguan dalam aktivitas penjualannya. Agar perusahaan dapat beroperasional dengan baik untuk menghasilkan produk yang dibutuhkan oleh konsumen, pengadaan persediaan oleh perusahaan harus efektif dan efisien, sehingga tidak terjadi persediaan yang menumpuk akibat pembelian dalam jumlah besar. Persediaan yang menumpuk tentunya akan mengakibatkan bertambah- nya biaya penyimpanan di gudang dan juga kualitas barang yang ada semakin lama akan semakin berkurang. Dalam hal ini belum terlaksananya pengelolaan akuntansi persediaan yang baik.

Penerapan akuntansi persediaan yang baik, dibutuhkan metode pencatatan dan penilaian yang benar terhadap persediaan karena pada proses normal, persediaan akan mengalami suatu perubahan dan untuk mengetahui perubahan tersebut, pencatatan dan penilaian yang tepat sangat penting 
artinya untuk menentukan harga pokok persediaan yang sesuai sehingga perusahaan tidak akan mengalami kerugian.

Sistem persediaan yang baik dapat terlihat dari bagaimana suatu persediaan dilaporkan secara benar dan akurat dalam neraca perusahaan. Agar hal tersebut dapat tercapai, dibutuhkan kembali ketelitian dan ketepatan dalam hal pencatatan, penilaian dan penetapan harga pokok. Hal ini selain sangat berpengaruh dalam laporan keuangan perusahaan, juga akan berpengaruh pada pengawasan terhadap persediaan perusahaan yang secara tidak langsung juga berkaitan dengan pengawasan terhadap karyawan perusahaan itu sendiri.

Pengaruh lain dari penetapan harga pokok persediaan yaitu terhadap peng- ambilan keputusan bagi pihak-pihak yang berkepentingan dengan perusahaan, bagi pihak internal maupun eksternal perusahaan. Bagi pihak internal, misalnya keputusan mengenai harga pokok penjualan sedangkan bagi pihak eksternal yaitu dalam hal investasi pada perusahaan yang bersangkutan, para kreditur dapat mengetahui kondisi perusahaan melalui laporan aktiva lancar pada perusahaan tersebut, mengetahui informasi mengenai laba per lembar saham serta tentang sumber-sumber modal sendiri perusahaan sehingga dapat diambil keputusan yang baik dan tepat.

Penerapan akuntansi persediaan dalam pelaksanaannya akan mengikuti bentuk dan jenis serta kebijakan yang diterapkan oleh perusahaan sesuai dengan kebutuhan perusahaan, sehingga perlu adanya standarisasi yang berlaku umum agar hasil akhir dari sistem akuntansi persediaan tersebut dapat dipahami oleh pihak-pihak yang berkepentingan dengan perusahaan tersebut. Untuk itu Ikatan akuntansi Indonesia sebagai lembaga yang berwenang memberikan pedoman/standa- risasi pelaksanaan sistem akuntansi keuangan di Indonesia telah mengatur mengenai perihal persediaan ini secara khusus melalui Pernyataan Standar Akuntansi Keuangan (PSAK) No.14 yang mengatur perlakuan akuntansi persediaan. UD Kaltim Makmur adalah distributor yang menyalurkan Air Mineral Aqua. Distribusi masukkeluarnya persediaan Air Mineral Aqua pada UD Kaltim Makmur cukup tinggi, sehingga perlunya perhatian khusus terhadap akuntansi persediaan yang dilaksanakannya. Dalam menjalankan aktivitasnya, UD Kaltim Makmur mendatangkan barang-barang melalui prosedur penerimaan, penyim- panan dan pengeluaran persedian yang semua kegiatan tersebut memerlukan pengawasan yang memadai terhadap persediaan tersebut, sehingga tujuan perusahaan untuk mencapai laba yang optimal dapat terwujud. Sebagaimana perusahaan dagang lainnya, persediaan Air Mineral Aqua bagi UD Kaltim Makmur mempunyai arti yang sangat penting karena merupakan penyokong utama operasi perusahaan.

Persediaan Air Mineral Aqua pada UD Kaltim Makmur haruslah dikelola dengan baik agar tetap tersedia untuk memenuhi kebutuhan konsumen. Pengelolaan persediaan tersebut termasuk dalam hal metode pencatatan dan penilaian persediaan yang diterapkan UD Kaltim Makmur. Metode pencatatan persediaan yang digunakan UD Kaltim Makmur adalah sistem periodik. Sistem periodik atau fisik merupakan sistem pencatatan persediaan dimana harga pokok penjualan dihitung secara periodik dengan mengandalkan semata-mata pada perhitungan fisik tanpa menyelenggarakan pencatatan pada kartu persediaan untuk masingmasing item persediaan.

UD Kaltim Makmur melakukan penilaian persediaan dengan metode rata- rata. Hal ini dimaksudkan apabila terjadi kenaikan atau penurunan harga, UD Kaltim Makmur akan menentukan harga jual barangnya diantara harga pembelian terdahulu dan harga pembelian terbaru kemudian ditambah persentase labanya. Permasalahan yang dihadapi oleh UD Kaltim Makmur dalam pencatatan persediaan menggunakan sistem periodik ini adalah adanya kesulitan dalam pengawasan jumlah stok barangnya, dikarenakan jumlah stok yang cukup banyak.

Pembelian persediaan Air Mineral Aqua selama tahun 2018 setiap bulannya rata-rata: Aqua kemasan botol 1500ml sebanyak 15.482 dos, Aqua kemasan botol $600 \mathrm{ml}$ sebanyak 16.640 dos, Aqua kemasan gelas $220 \mathrm{ml}$ sebanyak 6.400 dos, dan Aqua kemasan galon 19lt sebanyak 3.800 botol. Apabila ada stok barang yang hilang atau terjadi kesalahan perhitungan keluar atau masuknya barang di gudang, maka keadaan tersebut tidak dapat diketahui dengan segera dan karyawan UD Kaltim Makmur tidak memiliki catatan baku yang memuat historis persediaan barang di gudang. Akan mengalami kesulitan untuk mengetahui jumlah persediaan barang secara pasti apabila sewaktu-waktu dibutuhkan.

Penilaian persediaan barang dengan merataratakan harga jual yang dilakukan pimpinan UD Kaltim Makmur, sebenarnya hanya berdasarkan intuisi dan perkiraan pimpinan saja dengan memperhatikan harga jual pasar dan riwayat persediaan barang tersebut sebelumnya. Metode penilaian tersebut juga menjadi permasalahan karena harga pokok penjualannya tidak terukur dengan baik 
dan tidak dapat dijadikan patokan yang pasti untuk perencanaan laba perusahaan.

\section{TINJAUAN TEORETIS}

\section{Akuntansi Keuangan}

Akuntansi menghasilkan informasi yang menjelaskan kinerja keuangan entitas dalam suatu periode tertentu dan kondisi keuangan entitas pada tanggal tertentu (Martani, Veronica, Wardhani, Farahmita dan Tanujaya, 2012:4). Akuntansi merangkum transaksi yang terjadi dalam sebuah perusahaan kemudian memproses dan meyajikannya dalam bentuk laporan yang diberikan kepada para pengguna.

Jusup (2012:4-5), akuntansi dapat didefinisikan dari dua sudut pandang, yaitu dari sudut pemakai jasa akuntansi dan dari sudut proses kegiatannya. Ditinjau dari sudut pemakainya: akuntansi adalah suatu disiplin yang menyediakan informasi yang diperlukan untuk melaksanakan kegiatan secara efisien dan mengevaluasi kegiatankegiatan suatu entitas. Ditinjau dari sudut kegiatannya: akuntansi adalah proses pencatatan, penggolongan, peringkasan, pelaporan dan penganalisaan data keuangan suatu entitas.

Definisikan akuntansi menurut Kieso, dkk. (2010) dalam Martani, dkk. (2012:4), adalah suatu sistem dengan input data/ informasi dan output berupa informasi dan laporan keuangan yang bermanfaat bagi pengguna internal maupun eksternal entitas.

\section{Akuntansi Perusahaan Dagang}

Perusahaan dagang adalah perusahaanperusahaan yang bergerak dalam bidang pembelian dan penjualan barang. Perusahaan- perusahaan tersebut dapat dibedakan antara pedagang besar (grosir/ wholesaler) dan pedagang eceran (retail, agen dan toko) (Jusup, 2012:341). Grosir biasanya membeli barang langsung dari pabrik penghasil barang tersebut (produsen), sedangkan pedagang eceran membeli barang dari grosir untuk kemudian menjual kembali barang tersebut kepada konsumen (end user) dengan harga eceran.

Sumber pendapatan utama sebuah perusahaan dagang adalah penjualan barang dagangan yang disebut pendapatan penjualan atau disingkat penjualan. Dalam hal beban, perusahaan dagang mempunyai dua kelompok beban yang disebut beban pokok penjualan dan beban operasi. Beban pokok penjualan adalah jumlah harga pokok semua barang yang terjual sepanjang periode. Beban ini langsung berkaitan dengan pendapatan yang diakui dari hasil penjualan barang (Jusup, 2012:343).

\section{Persediaan}

Persediaan merupakan aktiva lancar terbesar dari perusahaan manufaktur maupun dagang. PSAK No.14 (revisi 2008) menerangkan bahwa persediaan adalah aset: a. Tersedia untuk dijual dalam kegiatan usaha biasa; b. Dalam proses produksi untuk penjualan tersebut; atau c. Dalam bentuk bahan atau perlengkapan untuk digunakan dalam proses produksi atau pemberian jasa (Ikatan Akuntan Indonesia, 2008:14.2).

Menurut Skousen dan Stice (2012:653), persediaan ditujukan untuk barang-barang yang tersedia untuk dijual dalam kegiatan bisnis normal dan dalam kasus perusahaan manufaktur, maka kata ini ditujukan untuk proses produksi atau yang ditempatkan dalam kegiatan produksi. Weygandt, dkk. (2010:443) mendefinisikan persediaan (inventory) adalah pos-pos aktiva yang dimiliki untuk dijual dalam operasi bisnis normal atau barang yang akan digunakan atau dikonsumsi dalam memproduksi barang yang akan dijual.

Istilah persediaan yang digunakan untuk menunjukkan barang- barang yang dimiliki oleh suatu perusahaan akan tergantung pada jenis usaha perusahaan. Secara umum istilah persediaan barang dipakai untuk menunjukkan barang-barang yang dimiliki untuk dijual kembali atau digunakan untuk memproduksi barang-barang yang akan dijual (Baridwan, 2008:149)

\section{METODE PENELITIAN \\ Definisi Operasional}

a. Persediaan adalah barang dagang berupa Air Mineral Aqua yang dibeli oleh UD Kaltim Makmur di Tanjung Redeb untuk dijual kembali tanpa mengalami proses produksi/ perubahan lainnya.

b. Metode pencatatan persediaan yaitu metode pencatatan akuntansi persediaan Air Mineral Aqua pada UD Kaltim Makmur di Tanjung Redeb.

c. Pernyataan Standar Akuntansi Keuangan (PSAK) No.14 adalah aturan atau norma-norma mengenai standarisasi perlakuan akuntansi keuangan terhadap persediaan barang.

\section{Unit Analisis, Populasi dan Sampel}

Unit analisis dalam penelitian ini adalah UD Kaltim Makmur yang beralamat di Jalan AKB Sanipa 2 RT.36 Kelurahan Tanjung Redeb Kecamatan Tanjung Redeb Kabupaten Berau. 
Populasi dalam penelitian ini adalah seluruh data pembelian dan penjualan persediaan Air Mineral Aqua pada UD Kaltim Makmur di Tanjung Redeb.

Sampel yang digunakan dalam penelitian ini adalah data pembelian dan penjualan persediaan Air Mineral Aqua kemasan 600ml pada UD Kaltim Makmur di Tanjung Redeb selama bulan Januari Tahun 2019. Penerapan metode pen- catatan pada persediaan Air Mineral Aqua kemasan 600ml ini merupakan representasi dari metode pencatatan persediaan Air Mineral Aqua yang digunakan UD Kaltim Makmur untuk jenis persediaan Air Mineral Aqua kemasan lainnya.

\section{ALAT ANALISIS}

Metode analisis yang digunakan dalam penulisan skripsi ini adalah analisis deskriptif kuantitatif, yaitu menggolong- kan data dan menguraikan secara deskriptif hasil penelitian yang dilakukan, serta mengambil suatu kesimpulan berdasarkan pada PSAK No.14 tentang persediaan, yaitu: sistem periodik dan sistem perpetual.

\section{DATA HASIL PENELITIAN}

\section{Pencatatan Persediaan}

UD Kaltim Makmur melakukan pencatatan persediaan Air Mineral Aqua dengan menggunakan metode pencatatan sistem periodik. Nilai persediaan Air Mineral Aqua dihitung pada akhir bulan sebelum pembuatan laporan keuangan bulanan dengan melakukan pemeriksaan fisik atau stok opname untuk mencatat persediaan akhir Air Mineral Aqua.

2. Pembelian dan Penjualan Air Mineral Aqua

UD Kaltim Makmur selama bulan Januari Tahun 2019 melakukan pembelian dan penjualan Air Mineral Aqua kemasan botol 600ml dengan rincian sebagai berikut:

Tabel 1. Pembelian Air Mineral Aqua 600ml Januari 2019

\begin{tabular}{|c|c|c|c|}
\hline Tauyzal & Kuautilax (cri) & $\begin{array}{c}\text { Farga Beli } \\
\text { /ert (RPp) }\end{array}$ & Juanlaht \\
\hline DSOLYONO19 & 1.280 & 47.480 & 60.774 .400 \\
\hline $11 / 01 ; 2019$ & 1.280 & 47.480 & 60.774 .400 \\
\hline $14 \% 01 / 2019$ & 1.280 & 47.480 & 60.774 .400 \\
\hline $15 \% 01 / 2019$ & 2.560 & 47.480 & 121.548 .800 \\
\hline $16001 / 2019$ & 2.560 & $\angle 7.450$ & 121.5 .48 .800 \\
\hline $21 / 01: 3019$ & 1.280 & 47.480 & 60.774 .400 \\
\hline $22 \% 01 / 2019$ & 2.560 & 47.480 & 121.548 .800 \\
\hline $23 \% 01: 2019$ & 1.280 & 47.480 & 60.774 .400 \\
\hline $74 / 01 / 2019$ & 2.560 & 47.480 & $121,548,800$ \\
\hline $28 / 01 / 2019$ & $1.2 \mathrm{so}$ & $\angle 7.450$ & 60.774 .400 \\
\hline $2901 / 2019$ & 2.560 & 67.480 & 121.548 .800 \\
\hline $31 / 01 / 2019$ & 1.280 & 47.480 & 60.774 .400 \\
\hline Total & 21.760 & & 1.033 .164 .800 \\
\hline
\end{tabular}

Berdasarkan tabel di atas, maka dapat dilihat bahwa selama bulan Januari Tahun 2019 pembelian Air Mineral Aqua kemasan botol 600ml sebanyak 21.760 crt (karton/dos) senilai Rp1.033.164.800,00.
Selama bulan tersebut harga beli tidak ada perubahan setiap terjadinya transaksi pembelian.

Tabel 2. Penjualan Air Mineral Aqua 600ml Januari 2019

\begin{tabular}{|c|c|c|c|}
\hline Tanggal & Knantitas (crt) & $\begin{array}{l}\text { Harga Jual } \\
\text { /ert (Rp) }\end{array}$ & Jumlah \\
\hline $0901 / 7019$ & 4. & 55000 & 200000 \\
\hline $03 \% 1 / 2019$ & 22 & 55.000 & 1.210 .000 \\
\hline $0401 / 2019$ & 11 & 55.000 & 7,0000 \\
\hline $05 / 01 / 2019$ & 10 & 55.000 & 550.000 \\
\hline $0801 / 2019$ & 564 & 55.000 & 31.020 .000 \\
\hline $0,001 / 2019$ & 244 & 55.000 & 13.420 .000 \\
\hline $10001 / 2019$ & 312 & 55000 & 17.160 .000 \\
\hline $11 / 91 / 2019$ & 518 & 55.000 & 30.140 .000 \\
\hline $1201 / 2019$ & 661 & 55.000 & 36.355 .000 \\
\hline $14 / 01 / 2019$ & 882 & 55.000 & 48.510 .000 \\
\hline $15.901 / 2019$ & 628 & 55.000 & 34540000 \\
\hline $1601 / 2019$ & 1.947 & 55.000 & 107.085 .000 \\
\hline $1701 / 2019$ & 1.038 & 55,000 & 57,090000 \\
\hline $1801 / 2019$ & 910 & 55.000 & 50.050 .000 \\
\hline $19.01 / 2019$ & 834 & 55.000 & 45.870 .000 \\
\hline $2101 / 2019$ & 1653 & 55.000 & 90.915 .000 \\
\hline $22 \% 1 / 2019$ & 924 & 55.000 & 50,820000 \\
\hline $23,801 / 2019$ & 1.270 & 55.000 & 69.850 .000 \\
\hline $2401 / 2019$ & 826 & 55.000 & 45.430 .000 \\
\hline $25 \% 1 / 2019$ & 1424 & 55.000 & 78.320 .000 \\
\hline $2601 / 2019$ & 982 & 55.000 & 54.010 .000 \\
\hline $28.91 / 2019$ & 913 & 55.000 & 50215,000 \\
\hline $29,01 / 2019$ & 1.220 & 55.000 & $57.100,000$ \\
\hline $3001 / 2019$ & 1455 & 55.000 & 80.025 .000 \\
\hline $31 / 01 / 2019$ & 1.318 & 55.000 & 72.490 .000 \\
\hline Total & 20.603 & & 1.133 .165 .000 \\
\hline
\end{tabular}

Tabel di atas menunjukkan jumlah penjualan Air Mineral Aqua kemasan botol 600ml selama bulan Januari Tahun 2019 yaitu sebanyak $20.603 \mathrm{crt}$ dengan nilai Rp1.133.165.000,00. Selama bulan tersebut harga jual tidak ada perubahan setiap terjadinya transaksi penjualan. Harga jual ditetapkan sama untuk setiap jenis pelanggan, seperti: mini market/swalayan, agen, toko, warung kecil, maupun perorangan (end user).

\section{ANALISIS DAN PEMBAHASAN \\ Analisis}

Perbandingan metode pencatatan persediaan untuk menentukan persediaan akhir dan harga pokok penjualan menurut UD Kaltim Makmur (metode periodik) dengan metode pencatatan lainnya, yaitu: metode periodik dengan rumus biaya FIFO (First In First Out), LIFO (Last In First Out) dan Rata-rata Sederhana, serta metode perpetual dengan rumus biaya FIFO (First In First Out), LIFO (Last In First Out) dan Rata-rata Bergerak 
Metode Periodik - FIFO (First In First Out)

\begin{tabular}{|c|c|}
\hline Perediasn awal Jarusri $20: 9$ & $\mathrm{~B}, 02.334 .000,00$ \\
\hline Pesnbelian selama Januari 2019 & Ixpl.033.164.800,00 \\
\hline Percediasn tersedia dijual & Egl.035.538.800,00 \\
\hline Persediazn akher Jarumari 2019 & $\operatorname{Rp} 57,308360,00$ \\
\hline Harga Pokok Penjualan & Rp978.230.440,010 \\
\hline
\end{tabular}

Metode Periodik - LIFO (Last In First Out)

\begin{tabular}{|c|c|c|}
\hline Persediaan awal :anuari 2019 & Rp2.374.010,00 & \\
\hline Pembelian sela-na Januari 2019 & Rpl.033.264.800,00 & + \\
\hline Persedinan tersetin dijual & Rp $1035.538 .800,00$ & \\
\hline Persediaan akhir Janvari 2019 & $\operatorname{Rg} 57,308.360,00$ & - \\
\hline Harga Pokok Penjualan & Rp978.230.440,00 & \\
\hline
\end{tabular}

Metode Periodik - Rata-rata Sederhana

\begin{tabular}{|c|c|c|}
\hline Pecsediaan awal Zanuar 2019 & Rp2.374.000,00 & \\
\hline Pernbebun selena Januari 2019 & $\operatorname{Rp} 1.033 .164 .800,00$ & + \\
\hline Perrediaan tersedia dijual & Rp1.033.538.810,20) & \\
\hline Persed aan akhir Jamuari 2019 & $\operatorname{Ry} 57,308.360,00$ & - \\
\hline Harga Pokok Peujualan & Rp978.230.440,00 & \\
\hline
\end{tabular}

\section{Metode Perpetual - FIFO (First In First Out)}

Dalam metode ini diasumsikan bahwa harga pokok dari persediaan yang pertama kali masuk dari pembelian, dikeluarkan terlebih dahulu pada saat terjadi penjualan. Perhitungan harga pokok penjualan dengan menggunakan Metode Perpetual FIFO (First In First Out) disajikan pada Tabel 3. Berdasarkan tabel tersebut, dapat diketahui bahwa pada tanggal 31 Januari 2019, persediaan akhir Air Mineral Aqua kemasan botol $600 \mathrm{ml}$ sejumlah 1.207 crt@Rp47.480,00 sehingga nilai persediaan akhir pada tanggal tersebut adalah sejumlah Rp57.308.360,00.

\section{Metode Perpetual - LIFO (Last In First Out)}

Dalam metode ini diasumsikan bahwa harga pokok dari persediaan yang terakhir masuk dari pembelian, dikeluarkan terlebih dahulu pada saat terjadi penjualan. Perhitungan harga pokok penjualan dengan menggunakan Metode Perpetual LIFO (Last In First Out) disajikan pada Tabel 4. Berdasarkan tabel tersebut, dapat diketahui bahwa pada tanggal 31 Januari 2019, persediaan akhir Air Mineral Aqua kemasan botol 600ml sejumlah 1.207 crt @ Rp47.480,00 sehingga nilai persediaan akhir pada tanggal tersebut adalah sejumlah Rp57.308.360,00.

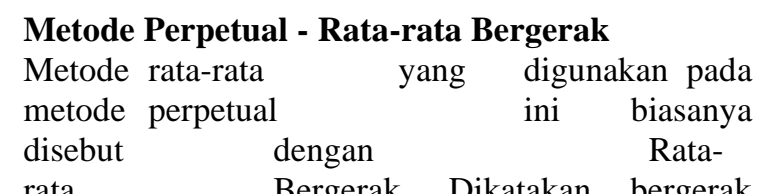
Bergerak. Dikatakan bergerak karena harga per unit persediaan selalu bergerak / berubah sesuai dengan terjadinya perubahan / mutasi pada jumlah unit persediaan yang dimiliki perusahaan. Perhitungan harga pokok penjualan dengan menggunakan Metode Perpetual - Rata-rata Bergerak disajikan pada Tabel 5. Berdasarkan tabel tersebut, dapat diketahui bahwa pada tanggal 31 Januari 2019, persediaan akhir Air Mineral Aqua kemasan botol 600ml sejumlah 1.207 crt @ Rp47.480,00 sehingga nilai persediaan akhir pada tanggal tersebut adalah sejumlah Rp57.308.360,00. Hasil perbandingan metode pencatatan persediaan untuk menentukan nilai persediaan akhir dan harga pokok penjualan menurut UD Kaltim Makmur (metode periodik) dengan metode pencatatan lainnya, yaitu: metode periodik dengan rumus biaya FIFO (First In First Out), LIFO (Last In First Out) dan Rata- rata Sederhana, serta metode perpetual dengan rumus biaya FIFO (First In First Out), LIFO (Last In First Out) dan Rata- rata Bergerak disajikan pada Tabel 3. 
Tabel 3. Kartu Persediaan Air Mineral Aqua 600ml Bulan Januari 2019 Dengan Metode Perpetual FIFO

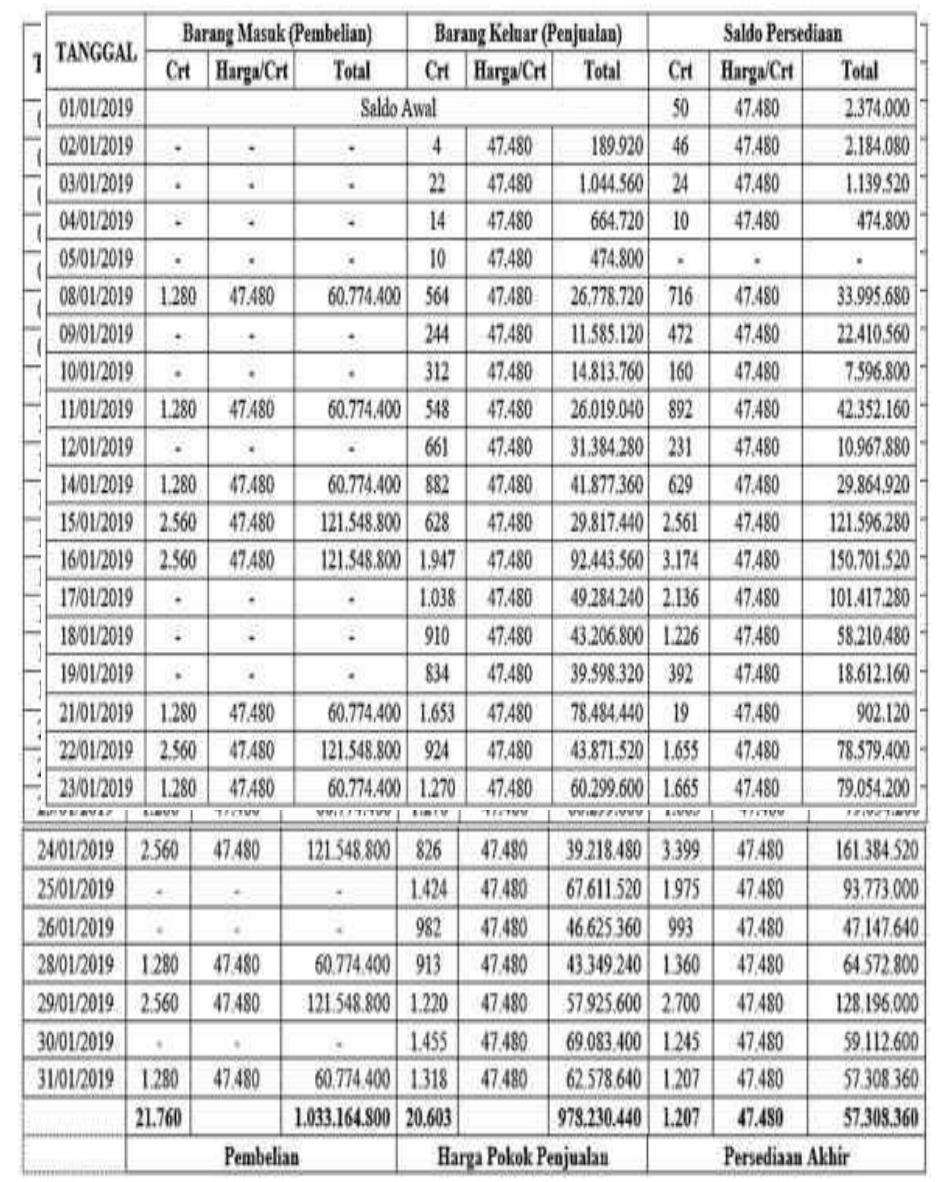

Tabel 4. Kartu Persediaan Air Mineral Aqua 600ml Bulan Januari 2019 Dengan Metode Perpetual LIFO

\begin{tabular}{|c|c|c|c|c|c|c|c|c|c|}
\hline 24012019 & 2.560 & 47.480 & 121.548 .800 & 826 & 47.480 & 39.218 .480 & 3399 & 47.480 & 161.384 \\
\hline 25012019 & • & - & - & 1.424 & 47. 480 & 67.611 .520 & 1975 & 47,480 & 93.773 \\
\hline 260120019 & . & . & . & 982 & 47,480 & 46.625 .360 & 993 & 47.480 & 47.147 \\
\hline 2801/2019 & 1.280 & 47.480 & 60.774.400 & 913 & 47. .480 & 43.34 .240 & 1360 & 47.880 & 64.572 \\
\hline 29012019 & 2.560 & 47.480 & 121.5158.800 & 1220 & 47:480 & 579256000 & 2700 & 47,680 & 128.196 \\
\hline 30012019 & 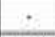 & . & . & 1.455 & 47.480 & 60.033 .900 & 1245 & 47.480 & 59.112 \\
\hline 31012019 & 1280 & 47,480 & 60.774 .400 & 1318 & 47.480 & 62.578 .440 & 1207 & 47,480 & 57308 \\
\hline & 21.760 & & 1.033 .164 .800 & 20.603 & & 978.230 .440 & 1.207 & 47,480 & 57.308 \\
\hline & \multicolumn{3}{|c|}{ Penbelian } & \multicolumn{3}{|c|}{ Harga Pokokokeujualan } & \multicolumn{3}{|c|}{ Persediaan Alkhir } \\
\hline
\end{tabular}

Tabel 5. Kartu Persediaan Air Mineral Aqua 600ml Bulan Januari 2019 Dengan Metode Perpetual Rata-rata Bergerak
Tabel 6. Hasil Perbandingan Metode Pencatatan Persediaan

\begin{tabular}{|c|c|c|c|c|c|c|c|c|c|}
\hline \multirow{2}{*}{ TANGGAL } & \multicolumn{3}{|c|}{ Barang Masuk (Pembellau) } & \multicolumn{3}{|c|}{ Barang Keluar (Peajualaa) } & \multicolumn{3}{|c|}{ Saldo Persedlaan } \\
\hline & $\mathrm{Crt}$ & $\mathrm{Harza} / \mathrm{Crt}$ & Total & $\mathrm{Crt}$ & Harga $\mathrm{Crt}$ & Total & $\mathrm{Cat}$ & $\mathrm{Harga} / \mathrm{Crt}$ & Total \\
\hline \multirow{2}{*}{$\frac{01 / 01 / 2019}{0201 / 2019}$} & \multicolumn{6}{|c|}{ Saldo Awal } & 50 & 47.480 & $2,374,000$ \\
\hline & - & - & $\cdot$ & 4 & 47.480 & 189.920 & 46 & 47.480 & 2.184 .080 \\
\hline $0301 / 2019$ & . & . & . & 22 & 47,480 & 1.044 .560 & 24 & 47,480 & $1.139,520$ \\
\hline 0401/2019 & . & . & . & 14 & 47.480 & 664.720 & 10 & 47.480 & 474.800 \\
\hline 051012019 & 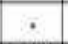 & . & + & 10 & 47,480 & 474.800 & . & $\cdot$ & $\cdot$ \\
\hline $0801 / 2019$ & 1.280 & 47.480 & $60.774,400$ & 564 & 47,480 & 26.778 .720 & 716 & 47.480 & 33.995 .680 \\
\hline $09 / 01 / 2019$ & $\cdot$ & $\cdot$ & $\cdot$ & 24 & 47.480 & 11.585 .120 & 472 & 47.480 & 22.410 .560 \\
\hline $1001 / 2019$ & . & $\cdot$ & . & 312 & 47,480 & 14.813 .760 & 160 & 47.480 & $7,596,800$ \\
\hline 11/01/2019 & 1280 & 47.480 & $60.774,400$ & 548 & & & 892 & & 42.352 .160 \\
\hline $1201 / 2019$ & $\cdot$ & $\cdot$ &. & 661 & 47,480 & 31.384 .280 & 231 & 47.480 & 10.967 .880 \\
\hline 1401/2019 & 1.280 & 47.480 & $60.774,400$ & 882 & 47.480 & 41.877 .360 & 629 & 47.480 & $29,864,920$ \\
\hline 15/01/2019 & 2.560 & 47,480 & 121.548 .800 & 628 & 47.480 & 29.817 .440 & 2.561 & 47.480 & 121.596 .280 \\
\hline 16012019 & 2.560 & 47.480 & 121.548 .800 & 1.947 & 47.480 & & 3.174 & 47.480 & \\
\hline 17012019 & $\cdot$ & $\cdot$ & $\cdot$ & 1.038 & 47.480 & 49.284 .240 & 2.136 & 47.480 & 101.417 .280 \\
\hline 1801/2019 & . & . & . & 910 & 47,480 & 43.206 .800 & 1.226 & 47.480 & 58.210 .480 \\
\hline 19/01/2019 & . & . & . & 834 & 47,480 & 39.598 .320 & 392 & 47.480 & 18.612 .160 \\
\hline 21012019 & 1.280 & 47.480 & $60,774,400$ & 1.693 & & & 19 & 47,480 & 902.120 \\
\hline $2201 / 2019$ & 2560 & 47.480 & 121.548 .800 & 924 & 47.480 & 43.871 .520 & 1.655 & 47.480 & 78.579 .400 \\
\hline $2301 / 2019$ & 1.280 & 47.480 & 60.774 .400 & 1.270 & 47.480 & 60.299 .600 & 1.665 & 47.480 & $79,054.200$ \\
\hline 24012019 & 2560 & 47.480 & 121548800 & 826 & 47.480 & 39.218480 & 3399 & 47.480 & 161384520 \\
\hline 25012019 & + &. & $\cdot$ & 1.424 & 47.480 & & 1975 & 47.480 & 93.773 .000 \\
\hline 26012019 & + & . &. & 982 & 47.480 & 46625360 & 993 & 47.480 & 47.147 .640 \\
\hline $2801 / 2019$ & 1280 & 47.480 & 60.774 .400 & 913 & 47.480 & 43.349 .240 & 1360 & 47,480 & 64572.800 \\
\hline $2901 / 2019$ & 2560 & 47.480 & 121.548 .800 & 1.220 & 47.480 & 57925.600 & 2700 & 47480 & 128.1960000 \\
\hline $3001 / 2019$ &. & . &. & 1.455 & 47.480 & 69.083 .400 & 1245 & 47.480 & 59112.600 \\
\hline $31 / 01 / 2019$ & 1280 & 47,480 & 60.774 .400 & 1318 & & 62.578 .640 & 1207 & 47.480 & 57308360 \\
\hline & 21.760 & & 1.033 .164 .900 & 20.603 & & 978.230 .440 & 1.207 & 47.450 & $57,3103,360$ \\
\hline & & Pembelia & & & ra Pokok Pe & eajualat & & Persediaal & \\
\hline & & Metode & & & crocdina & An Akbir & & $\begin{array}{l}\text { Harga } \mathrm{F} \\
\text { Peniu: }\end{array}$ & \\
\hline UD: & Kaltim & Makanur & & & & & & & \\
\hline Peric & atik-F & FIFO & & & & & & & 440 \\
\hline $\begin{array}{l}\text { Petix } \\
\text { Perio }\end{array}$ & odik I & Rama n:z. & Sederbana & & & $\frac{308.360}{308.360}$ & & & \\
\hline$P_{a x}$ & eteal - & FIFO & & & 57 & 308.360 & & 93828 & 449 \\
\hline Petp & cival - & LIFO & & & S7. & 368.369 & & 9782 & 440 \\
\hline & thene - & Rera-rate & & & $5 ?$ & 3016361 & & $928 \times 3$ & 440 \\
\hline
\end{tabular}

Tabel 6 di atas menunjukkan bahwa dari semua metode pencatatan memberikan nilai persediaan akhir dan harga pokok penjualan yang sama, hal ini dikarenakan selama bulan Januari 2019 tersebut harga pokok pembelian persediaan Air Mineral Aqua kemasan botol $600 \mathrm{ml}$ tidak ada perubahan harga.

\section{PEMBAHASAN}

Pernyataan Standar Akuntansi Keuangan (PSAK) No.14 mendefinisikan persediaan meliputi barang yang dibeli dan dimiliki untuk dijual kembali, hal ini telah sesuai dengan persediaan yang dimaksudkan pada UD Kaltim Makmur bahwa persediaan Air Mineral Aqua adalah barang yang 
dibeli dari pabrik dan dimiliki untuk dijual kembali kepada pelanggannya.

Metode pencatatan persediaan yang digunakan oleh UD Kaltim Makmur adalah metode periodik. Penggunaan metode pencatatan periodik pada UD Kaltim Makmur belum sesuai dengan PSAK No.14, dimana seharusnya meng-gunakan metode perpetual atau dengan penggunaan kartu persediaan. Pada saat transaksi pembelian persediaan dicatat dengan mendebit perkiraan persediaan bersangkutan dan mengkredit kas atau hutang. Pada saat penjualan, harga pokok barang yang terjual dicatat dengan mendebit harga pokok penjualan dan mengkredit persediaan tersebut.

Perhitungan fisik dilakukan pada setiap akhir bulan. Hal ini telah sesuai dengan PSAK No.14, dimana inven- tarisasi fisik perlu dilakukan untuk mengetahui kebenaran saldo perkiraan persediaan yang ada pada kartu persediaan yang telah dicatat dengan kondisi fisik persediaan yang ada di gudang, untuk mengetahui apakah nilai dan jumlah kuantitasnya telah sesuai atau tidak.

UD Kaltim Makmur melakukan perhitungan nilai persediaan tidak meng- gunakan rumus biaya yang diharuskan dalam PSAK No.14, sehingga metode yang digunakan UD Kaltim Makmur belum sesuai dengan PSAK No. 14. Rumus biaya yang disyaratkan adalah MPKP (masuk pertama keluar pertama), dimana nilai persediaan barang yang pertama dibeli akan dikeluarkan terlebih dahulu, sehingga nilai persediaan barang yang tertinggal di gudang (sebagai persediaan akhir) adalah nilai persediaan barang yang dibeli kemudian/setelahnya.

Perbandingan perlakuan akuntansi terhadap metode pencatatan persediaan Air Mineral Aqua pada UD Kaltim Makmur dengan Pernyataan Standar Akuntansi Keuangan (PSAK) No.14 tentang persediaan, sebagai berikut:

Tabel 7. Perbandingan Metode Pencatatan Persediaan menurut PSAK No.14 dan Menurut UD Kaltim Makmur

\begin{tabular}{|c|c|c|}
\hline PGAKND.14 & CD Kaldin Malkuar & $\begin{array}{c}\text { Sesuai' bejum } \\
\text { Sosuai }\end{array}$ \\
\hline 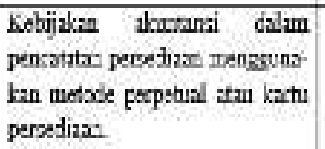 & 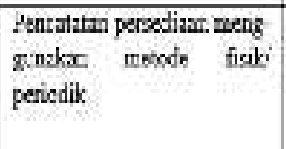 & Belum Sesai \\
\hline 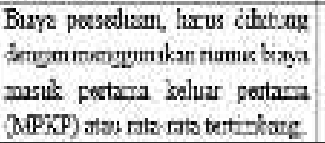 & 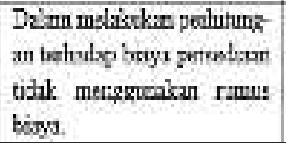 & Belum Sevis \\
\hline
\end{tabular}

Dengan demikian dapat disimpulkan bahwa menerima hipotesis dalam penelitian ini karena terbukti bahwa penerapan metode pencatatan persediaan Air Mineral Aqua pada UD Kaltim
Makmur belum sesuai dengan PSAK No.14 tentang persediaan.

\section{SIMPULAN DAN SARAN}

\section{SIMPULAN}

Berdasarkan analisis dan pembahasan pada bab sebelumnya maka dapat diambil kesimpulan bahwa penerapan metode pencatatan persediaan Air Mineral Aqua pada UD Kaltim Makmur belum sesuai dengan PSAK No.14. Metode pencatatan persediaan yang digunakan oleh UD Kaltim Makmur adalah metode periodik. Penggunaan metode pencatatan periodik pada UD Kaltim Makmur belum sesuai dengan PSAK No.14, dimana seharusnya menggunakan metode perpetual atau dengan penggunaan kartu persediaan. UD Kaltim Makmur melakukan perhitungan nilai persediaan tidak menggunakan rumus biaya yang disyaratkan dalam PSAK No.14, sehingga metode yang digunakan UD Kaltim Makmur belum sesuai dengan PSAK No. 14.

Perbandingan metode pencatatan persediaan untuk menentukan nilai persediaan akhir dan harga pokok penjualan menurut UD Kaltim Makmur (metode periodik) dengan metode pencatatan lainnya, yaitu: metode periodik dengan rumus biaya FIFO (First In First Out), LIFO (Last In First Out) dan Rata- rata Sederhana, serta metode perpetual dengan rumus biaya FIFO (First In First Out), LIFO (Last In First Out) dan Rata- rata Bergerak, menunjukkan bahwa nilai persediaan akhir dan harga pokok penjualan yang sama. Hal ini dikarenakan selama bulan Januari 2019 tersebut harga pokok pembelian persediaan Air Mineral Aqua kemasan botol $600 \mathrm{ml}$ tidak ada perubahan harga.

\section{SARAN}

Disarankan kepada UD Kaltim Makmur agar dapat mengganti sistem pencatatan persediaannya sesuai dengan yang disyaratkan dalam PSAK No. 14, yaitu metode perpetual atau dengan penggunaan kartu persediaan. Hal ini dikarenakan akan ada banyak keuntungan yang didapatkan dengan menggunakan metode pencatatan perpetual. Keuntungan tersebut diantaranya: perusahaan dapat memonitor persediaannya sewaktu-waktu tanpa harus menghitung ulang dulu di gudang, keputusan manajemen mengenai persediaan dapat diambil dengan segera contohnya pada saat akan melakukan pembelian barang dagangan. Lebih baik lagi apabila metode pencatatan persedianya sudah terintergrasi dengan 
system akuntansi yang lain dalam suatu program komputer akuntansi, sehingga dapat efisiensi dan efektifitas kerja manajemen.

\section{DAFTAR PUSTAKA}

Afni, Noor. 2015. Penerapan Metode Pencatatan dan Penilaian Terhadap Persediaan Barang Menurut PSAK No.14 pada CV Metro Elektronik di Kabupaten Berau. Skripsi. STIE Muhammadiyah Tanjung Redeb, Berau.

Anonim. 2012. Al-Quran dan Terjemah- nya. Departemen Agama RI, Jakarta.

Anwar, Nurul Fitah. 2014. Analisis Penerapan Metode Pencatatan dan Penilaian Terhadap Persediaan Barang Menurut PSAK No.14 pada PT. Tirta Investama DC Manado. ISSN 23031174. Jurnal EMBA, Akuntansi Keuangan No.1: Penyajian Laporan Keuangan (Revisi 2013). Dewan Standar Akuntansi Keuangan, Jakarta.

Jusup, Al. Haryono. 2012. Dasar-dasar Akuntansi, Edisi 7, Jilid 1. BP STIE YKPN, Yogyakarta.

Martani, Dwi, Sylvia Veronica, Ratna Wardhani, Aria Farahmita dan Edward Tanujaya. 2012. Akuntansi Keuangan Menengah Berbasis PSAK, Buku 1. Salemba Empat, Jakarta.

Mulyadi. 2016. Sistem Akuntansi, Edisi 4. Salemba Empat, Jakarta.

Nuh, Muhamad dan Hamizar. 2007. Intermediate Accounting. Fajar, Jakarta.

Saepudin, Aep. 2013. Analisis Perlakuan Akuntansi atas Persediaan Barang Dagangan pada PT Millennium

Pharmacon International Tbk. Palem- bang. Skripsi. Fakultas Ekonomi Universitas IBA, Palembang.

Salangka, Ester. 2013. Penerapan Akuntansi Persediaan Untuk Perencanaan dan Pengendalian LPG pada PT Emigas Sejahtera Minahasa. Jurnal EMBA, Vol.1 No.3 September 2013, Hal. 1120-1128, ISSN: 23031174.

Sasongko, Catur, Agustin Setyaningrum, Annisa Febriana, Ayu Nadia Hanum, Aisyah Dian Pratiwi dan Vivi Zuryati. 2017. Akuntansi Suatu Pengantar Berbasis PSAK, Buku 1, Cetakan Keempat. Salemba Empat, Jakarta.

Siregar, Baldric, Bambang Suripto, Dody Hapsoro, Eko Widodo Lo dan Frasto Biyanto. 2013.

Akuntansi Manajemen. Salemba Empat, Jakarta. Skousen, K. Fred dan James D. Stice, 2012. Intermediate Accounting, Edisi Kedelapan belas. Salemba Empat,Jakarta.
Warsono, Sony dan Dian Andari. 2015. Akuntansi Dasar Untuk Perguruan Tinggi Islam. AB Publisher, Yogyakarta.

Weygandt, Jerry J., Donald E. Kieso dan Terry D. Warfield. 2010. Akuntansi Intermediate, Edisi Kesepuluh, Terjemahan Emil Salim. Erlangga, Jakarta.

Yamit, Z. 2010. Manajemen Persediaan. Ekonesia Kampus Fakultas Ekonomi UII, Yogyakarta. 